\title{
POLLEN FLOW ANALYSIS IN SUNFLOWER (Helianthus annuus L.)
}

\begin{abstract}
Alba, V.
Department of Agro-Forestry and Environmental Biology and Chemistry, Section of Genetics and Breeding, University of Bari, Italy
\end{abstract}

Received: September 10, 2009 Accepted: December 03, 2009

\section{SUMMARY}

Biofuels from wood, wastes and various agricultural crops are currently quite expensive. Seed oil plants, instead, represent a relevant renewable natural resource for biodiesel to be used as engine fuel. In consequence, new genetic modified varieties (GMV) have been obtained by biotechnological methods, which offer a wide range of special oils for bio-energetic purposes. However, growing sunflower GMVs for biodiesel production could create a potential risk due to pollen flow from transgenic to non-transgenic varieties when grown in the same geographic areas. Presently, pollen flow analysis by DNA-based tools is expensive and time consuming, and new, cheap and rapid methods are needed.

The goal of this research was to estimate pollen flow in sunflower by using a "composite" line, with a monogenic dominant marker (TT) for a high phenotypic expression of blue leaf nervure, as pollinator, and an inbred line and a cytoplasmic male sterile line ( $\mathrm{cms}$ ) as recipient plants.

The obtained results suggest that cytoplasmic male sterility could be used for the analysis of sunflower pollen flow.

\section{Key words: sunflower, pollen flow, cytoplasmic male sterility}

\section{INTRODUCTION}

Climate changes, rising oil prices and a concern for future supplies have led to an increased interest in the potential use of biomass for energy purposes. The EC is focusing on transport, which is responsible for about $21 \%$ of the EU's harmful greenhouse gas emissions and adopted an action plan to increase the use of biomass from forestry, agriculture and waste material. In 2001 the EU adopted a communication on alternative fuels for road transport, identifying three fuels (biofuels, natural gas, hydrogen) that could play a major role. Since the adoption of the communication, the marked share of biofuels has increased. But biofuels from wood, wastes and various agricultural crops are currently expensive. Plant oils, instead,

* Corresponding author: Phone/fax: 00390805442200; e-mail: totitoti@katamail.com 
and sunflower in particular, represent a relevant renewable natural resource, applicable in several food and non-food economic sectors. The application of genetic technologies allowed to engineer a metabolic pathway in some oilseed plants with the aim of producing oils for industrial applications. In consequence, new genetically modified varieties (GMV) of sunflower have been obtained, capable of offering a wide range of special oils.

Nowadays, the public gives attention to GMV cultivation, concerning gene flow from modified plants into their wild relatives or into cultivated varieties (Aria and Rieseberg, 1994; Guadagnuolo et al., 2001; Ritala et al., 2002). The European Community directive 2001/18/CE invites member countries to regulate the emission in the environment of any genetically modified organism (microorganisms, plants, animals) in order to avoid involuntary transfer of GMVs into conventional productions. An accurate environmental risk assessment, as a consequence of vertical or horizontal gene flow among vegetal communities caused by pollen migration, need to be undertaken. Pollen flow in crop plants has been widely investigated in the past mainly because of fears that seed lots would be contaminated by foreign germplasm. It is well-known that one of the high risk factors is GMV invasiveness (Wolfenbarger and Phifer, 2000) and their ecological impact in an ecosystem where they are not naturally present. In particular, many researchers (Scheffler and Dale, 1994; Ellstrand et al., 1999) evidenced that a transgene can confer a selective advantage to the modified organism. This advantage can be transmitted to relative wild plants or, alternatively, to non transgenic cultivars, through pollen migration, potentially creating invasive weeds or increasing the difficulty in weed control (Keeler and Turner, 1990; Manasse, 1992). On the other hand, the genetic diversity of a species could undergo a reduction due to a loss of adaptability induced by an accidentally received transgene. Hence, both cases could lead to changes in the ecological equilibrium of a species, particularly in centers of genetic origin (Ellstrand, 1988; Jorgensen et al., 1996). Some researches evidenced fertile crosses between crop plants and their wild relatives in several species: rapeseed (Brassica napus), sugar beet (Beta vulgaris), sunflower (Helianthus annuus) (Onofri et al., 2006). For these reasons, an eventual use of sunflower GMV could give raise to a risk of gene flow due to the presence of natural populations of ornamental and wild sunflower inter-fertile species (Monotti and Bonciarelli, 1992; Faure et al., 2002). It is fundamental, therefore, to define the optimal "insulating distances" between GM and traditional varieties, to prevent the risk of pollen pollution. Onofri et al. (2006) reported that several factors influence insulating distances: genetic traits, field size and dimension, direction of prevalent winds, presence of natural or artificial barriers, agronomic practices and sowing date. In any case, the EU trends in energetic strategies promote research on biofuel production from biomass and oleaginous crops, and among these, sunflower receives great attention. In that case the risk factor could be represented by pollen migration from sunflower GMVs selected for bio diesel production. 
Nowadays, DNA molecular analyses to identify transgenes in a plant are effective, precise, but very expensive and time consuming (Daniell, 2002). The goal of this research was to study a new strategy to estimate pollen flow in sunflower by means of a cheaper and faster method.

\section{MATERIAL AND METHODS}

The research took place in 2007 in two different environments in south Italy: Aradeo (Apulia region), and Matera (Basilicata region), geographical areas in which the main crop is wheat in rotation with herbaceous crops. Thus, no sunflower cultivation was present in the zones of the trials.

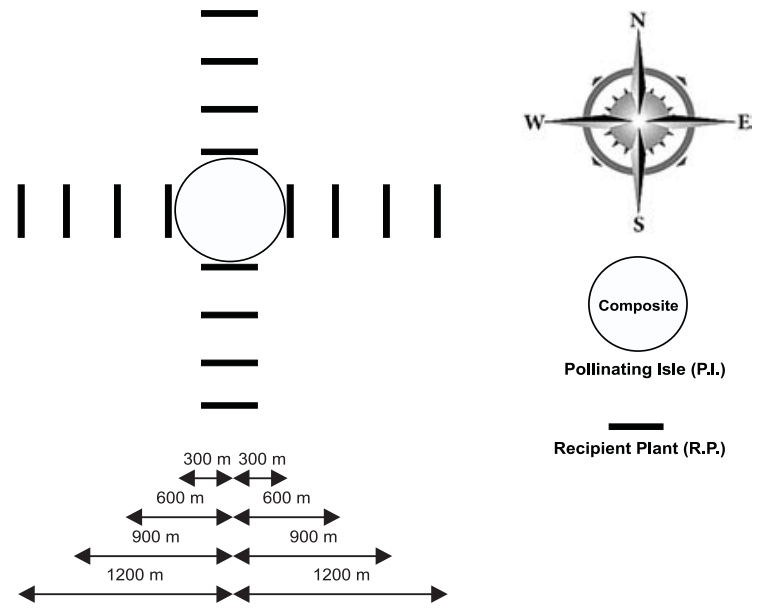

Figure 1: Experimental setup of the field trials to measure pollen flow in sunflower in Aradeo and Matera (South Italy).

The experimental design consisted of four concentric circles, with a plot used as pollinating patch (PI) in the center of the innermost circle, with a radius of 300 $\mathrm{m}$. The PI consisted of a "composite population" homozygous for alleles TT conferring an anthocyanin color to leaf nervure occurring after emergence of plantlets. The distance among each of the four circles was $300 \mathrm{~m}$, so that the maximum distance from the PI center to the outermost circle was $1200 \mathrm{~m}$. Four plots, each one of $220.5 \mathrm{~m}^{2}$ ( $4.9 \mathrm{~m} \times 45 \mathrm{~m}$ ) containing the recipient plants (RP), were located with the longer side along the tangents of each circumference in the direction of the 4 principal cardinal points (see figure). Plants were spaced $70 \mathrm{~cm}$ between rows and $30 \mathrm{~cm}$ in the row. In the trial at Aradeo, the RPs constituted of an inbred line with normal light green color of the leaf nervure, while in Matera a cytoplasmic male sterile (cms) line was used as RP. The sowing dates were $5^{\text {th }}$ March in Aradeo and $10^{\text {th }}$ March in Matera and the conventional agronomic practices for sunflower were applied. In Aradeo, the PI flowered from 18 May to 9 June, while the RP started to 
flower on 22 May and continued until 2 June. In Matera, the PI started to flower on 24 May and continued until 12 June, while the $\mathrm{cms}$ line started to flower on 29 May and continued until 10 June. The start of flowering was recorded when at least $5 \%$ of the plants showed open floral buds, the end of flowering when $95 \%$ of the plants showed open floral buds.

The harvest of each plot was conducted separately in both locations, on 3 and 4 August.

In Aradeo, the seeds from the RP were run through a blower to separate empty from full ones. Thousand seeds per single RP plot were sown in September in rows spaced $20 \mathrm{~cm}$ and plants spaced $10 \mathrm{~cm}$ in the row. At plantlet stage, between 27 and 30 September, plants showing the anthocyanin color of leaf nervure were counted to estimate the pollen flow. The frequency of pollen flow for each plot was estimated as the proportion of anthocyanin plants over total plants.

In Matera, seeds from 20 random heads was counted to estimate the average number of seeds (empty and full) produced per each cms plant; hence, seeds from each plot were run through a blower to separate empty seeds from full ones resulting from pollen flow. The frequency of pollen flow in the $\mathrm{cms}$ plots was calculated with a formula:

- frequency of pollen flow $=[a /(b \times c)] \times 100$

where:

$\mathrm{a}=$ full seeds

$\mathrm{b}=$ seed average per head

$\mathrm{c}=\mathrm{cms}$ plants per plot.

\section{RESULTS}

\section{Experiment field at Aradeo}

Not a single plantlet showing anthocyanin color of leaf nervure were obtained from the seeds produced in the plots $1200 \mathrm{~m}$ and $900 \mathrm{~m}$ away from the PI, for all the cardinal points. Seeds from the RP plots located at $600 \mathrm{~m}$ distance gave the following results:

- of the 960 plantlets obtained from seed in the northern plot, 24 plantlets showed the anthocyanin nervure $(2.5 \%)$;

- of the 972 plantlets obtained from seed of the southern plot, 13 plantlets showed the anthocyanin nervure (1.3\%);

- of the 957 plantlets obtained from seed in the eastern plot, 5 plantlets showed the anthocyanin nervure $(0.5 \%)$;

- no plantlet showed the anthocyanin nervure among those derived from seed in the western plot.

Concerning the plots $300 \mathrm{~m}$ away from the PI, the percentages of plantlets with anthocyanin nervure were high, indicating a considerable pollen migration that distance. 
Specifically:

- of the 984 plantlets obtained from seed in the northern plot, 61 plantlets showed the anthocyanin nervure $(6.2 \%)$;

- of the 991 plantlets obtained from seed in the southern plot, 36 plantlets showed the anthocyanin nervure (3.6\%);

- of the 972 plantlets obtained from seed in the southern plot, 34 plantlets showed the anthocyanin nervure $(3.5 \%)$;

- of the 945 plantlets obtained from seed in the southern plot, 28 plantlets showed the anthocyanin nervure (3.0\%).

\section{Experiment field at Matera}

The average number of seeds (empty and full) estimated for each $\mathrm{cms}$ plant was 194.

The $\mathrm{cms}$ plot located $1200 \mathrm{~m}$ away from the PI did not produce a single full seed, except for the southern plot in which 5 full seeds were obtained from $980 \mathrm{cms}$ plants $(0.003 \%)$.

The $\mathrm{cms}$ plots grown $900 \mathrm{~m}$ away from PI gave the following results:

- 26 full seeds from $1040 \mathrm{cms}$ plants $(0.01 \%)$ in the northern plot;

- 74 full seeds from $1020 \mathrm{cms}$ plants $(0.04 \%)$ in the southern plot;

- 138 full seeds from $990 \mathrm{cms}$ plants $(0.07 \%)$ in the eastern plot;

- 12 full seeds from $1050 \mathrm{cms}$ plants $(0.006 \%)$ in the western plot.

The numbers of full seeds recorded on the $\mathrm{cms}$ plants in the plots located 600 $\mathrm{m}$ and $300 \mathrm{~m}$ away were significantly higher, with larger numbers of full seeds in the southern and eastern plots.

The cms plots $600 \mathrm{~m}$ away from the PI gave the following results:

- 96 full seeds from $1033 \mathrm{cms}$ plants (0.05\%) in the northern plot;

- 104 full seeds from $1028 \mathrm{cms}$ plants (0.05\%) in the southern plot;

- 195 full seeds from $1020 \mathrm{cms}$ plants $(0.10 \%)$ in the eastern plot;

- 44 full seeds from $1045 \mathrm{cms}$ plants (0.02\%) in the western plot.

The $\mathrm{cms}$ plots grown $300 \mathrm{~m}$ away from the PI gave the following results:

- 201 full seeds from $1030 \mathrm{cms}$ plants $(0.10 \%)$ in the northern plot;

- 176 full seeds from $1019 \mathrm{cms}$ plants $(0.09 \%)$ in the southern plot;

- 234 full seeds from $1022 \mathrm{cms}$ plants $(0.12 \%)$ in the eastern plot;

- 148 full seeds from $1040 \mathrm{cms}$ plants $(0.07 \%)$ in the western plot.

\section{DISCUSSION}

The results of this research lead to interesting considerations concerning the analysis of pollen flow in sunflower. Differences in pollen flow were revealed in relation to the kind of recipient plant employed. The cytoplasmic male sterile line $(\mathrm{cms})$ showed a better efficiency for estimating pollen flow than the inbred line. In fact, in the experimentl field at Aradeo, the RP with a normal floral structure did not show 
pollen pollution from the composite population homozygous for alleles TT conferring an anthocyanin color to leaf nervure, in the circles $1200 \mathrm{~m}$ and $900 \mathrm{~m}$ away from the PI. Conversely, in the experiment field at Matera, positive results, even if limited to only 5 full seeds from the southern plot, were obtained at the distance of $1200 \mathrm{~m}$ from the PI. Furthermore, in this trial, pollen flow was evidenced in all plots $900 \mathrm{~m}$ away from the PI. In the eastern plot, particularly, 138 full seeds were recorded. These results agree with the high levels of pollen flow between cultivated and wild sunflower as reported by other authors (Arias and Rieseberg, 1994; Whitton et al., 1997).

Differences occurred between the two trials in terms of recipient plant, i.e., between the normal and the cms line, which can be ascribed both to the absence of pollen competition in the $\mathrm{cms}$ plants and to physiologically longer tendency of their gynoecia to receive pollen compared with a normal fertile line. In effect, in plants with normal fertility, the availability of pollen from the same flower and from the plants from the same plot, during flowering time, assures normal pollination processes. Conversely, in cms plants, the absence of pollen extends the period of tendency of stigmata to receive any kind of pollen.

On the other hand, the use of $\mathrm{cms}$ plants can be a useful monitoring instrument for in vivo detection of gene escape through wind-distributed pollen (Saeglitz et al., 2000). Moreover, Giddings et al. (1997a,b) showed that the amount of pollen flow did not decrease uniformly with distance, because weather conditions, especially wind speed and turbulence, made the pollen flight models complex and predictions difficult.

Besides, in allogamous plant species, like sunflower, with a completely efficient and functional floral structures, many factors can influence pollen flow. These factors can be resumed as follows:

- efficiency of fertile pollen production by pollinating parent;

- morphological and genetic compatibility between reproductive organs of the parents;

- allogamy/autogamy ratio;

- migration pollen efficiency, not strictly related to enthomophyli or anemophily;

- contemporaneous flowering time between parents;

- competition among pollens from different origin;

- distance between pollinating plants and recipient parent plants;

- dimension of pollen source (PI area) and receiving population (recipient plants);

- environmental factors (temperature, wind direction and intensity, local biodiversity at all levels, site topography, etc.).

For those reasons, the results of this report do not have to be definitive regarding about the use of the cms method for estimating the pollen flow in sunflower. The method has to be complemented with more complex protocols that involve all the components of the ecosystem. 
This report highlights how the difference between flow gene percentages, referred to the cardinal points, increases with distance from the pollinating patch. Thus the wind direction and intensity played a fundamental role, in particular northern winds in Aradeo and eastern winds in Matera which were prevalent in this research.

\section{REFERENCES}

Arias, D.M., Rieseberg, L.H., 1994. Gene flow between cultivated and wild sunflower. Theoretical and Applied Genetics 89: 655-660.

Daniell, H., 2002. Molecular strategies for gene containment in transgenic crops. Nature Biotechnology 20: 581-586.

Ellstrand, N.C., 1988. Pollen as vehicle for the escape of engineered genes? Tree 3: 30S-32S.

Ellstrand, N.C., Prentice, H.C., Hancock, J.F., 1999. Gene flow and introgression from domesticated plants into their relatives. Annual Review of Ecology and Systematics 30: 539-563.

Faure, N., Serieys, H., Bervillè, A., 2002. Potential gene flow from cultivated sunflower to volunteer, wild Helianthus species in Europe. Agriculture, Ecosystems and Environment 89: 183-190.

Guadagnuolo, R., Savova-Bianchi, D., Felber, F., 2001. Gene flow from wheat (Triticum aestivum L.) to jointed goatgrass (Aegilops cylindrica Host.), as revealed by RAPD and microsatellite markers. Theoretical and Applied Genetics 103: 1-8.

Giddings, G.D., Sackville Hamilton, N.R., Hayward, M.D., 1997a. The release of genetically modified grasses. Part 1: Pollen dispersal to traps in Lolium perenne. Theoretical and Applied Genetics 94: 1000-1006.

Giddings, G.D., Sackville Hamilton, N.R., Hayward, M.D., 1997b. The release of genetically modified grasses. Part 2: The influence of wind direction on pollen dispersal. Theoretical and Applied Genetics 94: 1007-1014.

Jorgensen, R.B., Hauser, T., Mikkelsen, T.R., Ostergard, H., 1996. Transfer of engineered genes from crop to wild plants. Trends in Plant Science 1: 356-358.

Keeler, K.H., Turner, C.E., 1990. Management of transgenic plants in the environment. In: Levin, M., Strauss, H. (eds.). Risk assessment in genetic engineering: environmental release of organisms. McGraw-Hill, New York, pp. 189-218.

Manasse, R.S., 1992. Ecological risks of transgenic plants: effects of spatial dispersion of gene flow. Ecological Applications 2: 431-438.

Monotti, M., Bonciarelli, U., 1992. Infestation of wild Helianthus annuus in cultivated sunflower in Italy: origin, spread and control. In: Proc of $15^{\text {th }}$ COLUMA Conference, International Meeting of Weed Control, Versailles, France, pp.701-707.

Onofri, A., Rosellini, D., Tei, F., Veronesi, F., 2006. Le piante geneticamente modificate nell'agricoltura Umbra. In: Coesistenza tra colture geneticamente modificate, convenzionali e biologiche nel contesto dell'agricoltura Umbra, Cornicchia Grafiche, Perugia, Italy pp.1-24. /ISBN 88-8762-11-2/.

Ritala, A., Nuutila, A.M., Aikasalo, R., Kauppinen, V., Tammisola, J., 2002. Measuring gene flow in the cultivation of transgenic barley. Crop Science 42: 278-285.

Saetz, C., Pohl, M., Bartsch, D., 2000. Monitoring gene flow from transgenic sugar beet using cytoplasmic male sterile bait plants. Molecular ecology 9: 2035-2040.

Scheffler, J.A., Dale, P.J., 1994. Opportunities for gene transfer from transgenic oilseed rape (Brassica napus) to related species. Transgenic Research 3: 263-278.

Whitton, J., Wolf, D.E., Arias, D.M., Snow, A.A. and Rieseberg, L.H., 1997. The persistence of cultivar alleles in wild populations of sunflowers five generations after hybridization. Theoretical and Applied Genetics 95: 33-40.

Wolfenbarger, L.L., Phifer, P.R., 2000. The ecological risks and benefits of genetically engineered plants. Science 290: 2088-2093. 


\title{
ANÁLISIS DEL FLUJO POLÍNICO EN GIRASOL (Helianthus annuus L.)
}

\author{
RESUMEN
}

Los biocombustibles obtenidos desde la madera, los residuos y los diversos cultivos agrícolas son caros. Las plantas oleaginosas representan un recurso renovable, porque de ellas se puede obtener biodiesel que puede utilizarse como combustible. Se han obtenido organismos genéticamente modificados (OGM) mediante biotecnologías, que ofrecen una amplia gama de aceites especiales con fines biológicos-energéticos. El uso de OGM en girasol, para producir biodiesel, podría incrementar el riesgo debido al flujo génico desde los transgénicos a los no transgénicos, cuando ambos tipos crecen en la misma área. Actualmente, el análisis de flujo de polen mediante análisis de ADN es costoso y lleva mucho tiempo. Por lo tanto, se necesitan nuevos métodos, más baratos y rápidos. El objetivo de esta investigación fue estimar el flujo de polen en girasol utilizando una línea "compuesta", con un marcador dominante monogénico (TT) para la alta expresión fenotípica de la nervadura azul en la hoja, utilizada como polinizadora, y una línea pura y otra línea con androesterilidad citoplasmática $(\mathrm{cms})$, como hembras. Los resultados sugieren el uso de la androesterilidad citoplasmática en pos de analizar el flujo de polen en girasol.

\section{ANALYSE DE LA DISPERSION DU POLLEN CHEZ LE TOURNESOL (Helianthus annuus $\mathrm{L}$.)}

\author{
RÉSUMÉ
}

Les "biofuels" organiques issus du bois, des déchets et de diverses récoltes végétales sont très onéreux. Les plantes oléagineuses, en revanche, représentent une ressource naturelle renouvelable appropriée pour le biodiesel employé comme carburant.

Par conséquent, de nouvelles variétés génétiquement modifiées (OGM) ont été obtenues par biotechnologie, offrant un large éventail d'huiles spéciales pour des applications bio-énergétiques.

Mais l'utilisation de tournesol OGM pour la production de biodiesel pourrait représenter un facteur de risque potentiel dû au transfert de pollen depuis les variétés transgéniques vers les plantes non transgéniques, si elles sont cultivées dans les mêmes zones géographiques.

De nos jours, l'analyse de dispersion du pollen par les méthodes basées sur l'ADN étant longue et chère, de nouveaux outils plus rapides et plus économiques sont nécessaires.

Le but de cette étude était d'estimer la dispersion du pollen de tournesol grâce à une lignée "composite", avec un marqueur monogénique dominant (TT) pour une forte expression phénotypique de la nervure bleue des feuilles, comme pollinisateur, et une lignée pure mâle-stérile $(\mathrm{cms})$ comme receveur.

Les résultats obtenus suggèrent d'employer la stérilité mâle cytoplasmique pour analyser la dispersion du pollen de tournesol. 